\title{
The future of child benefits in the United Kingdom
}

The implementation of the 1986 Social Security Act in April 1988 marked an important milestone in the development of financial support for children. Confronted by a substantial body of evidence which showed that poverty is most extreme among families with children, ${ }^{12}$ the government has chosen to shift the balance of support away from pensioners, single people, and higher income families towards families with children on very low incomes. In the context of social security spending as a whole, the size of the transfer which has been achieved is miniscule. Nevertheless, the move was a bold one in political terms as pensioners have long been regarded as one of the natural constituencies of the Tory party, while the history of child benefit is littered with political casualties. $^{3}$

\section{The aims of reform}

The 1986 Act followed a series of ministerial reviews, a green and a white paper. The government's intention in reviewing social security provisions was to arrive at a system that was: (a) capable of meeting genuine need; (b) consistent with its economic objectives; and (c) simpler to understand and easier to administer. ${ }^{4}$ No new money was to be made available.

The government, in its green paper, ${ }^{5}$ articulated 'two clear and distinct aims in helping families with the cost of bringing up children': (1) 'to provide help for families generally'; and (2) 'to provide extra help for low-income families.'

\section{A new benefit structure}

Child benefit, payable for all children under 16 , has been the principal mechanism for providing generalised financial assistance to families since its introduction in 1977. Although the government considered both means testing or taxing child benefit and 'fine tuning' it on particular types of family, all these strategies were rejected on practical grounds rather than for reasons of principle. ${ }^{5}$ While child benefit came out of the reviews unscathed (though see below), maternity grant has been made means tested and maternity allowance made taxable.

The most radical changes affected means tested benefits which are designed to provide extra help for low income families. Supplementary benefit, aimed primarily at those not in full time employment, was replaced by a combination of income support and interest free loans (payable under the new social fund) which take the place of the cash grants (single payments) that used to be available to meet exceptional needs. Family income supplement-for working families-was replaced by family credit while housing benefit, available to all low income householders regardless of employment status, was restructured but retains the same name.

Reflecting the aim of simplification and the desire to enhance work incentives, all three schemes share a related means test. A family is entitled to income support (and housing benefit) if their income is less than their requirements. Requirements are calculated as the sum of a personal allowance for the claimant (and his or her partner), an age related allowance for each child and a fixed family premium. The maximum family credit is payable to working families with net incomes at or below the personal allowance for a couple on income support and is progressively reduced for families on higher incomes.

\section{Impact of the reforms}

Family credit is more generous than family income supplement used to be and the government expects twice as many families (400000 in total) to be eligible. ${ }^{6}$ At face value children also gain under the new income support and housing benefit schemes, although entitlement to housing benefit stops at much lower income levels than before. Official figures indicate that $71 \%$ of two parent families entitled to means tested benefits are made better off as a result of the structural reforms, a fifth of them by over $£ 5$ per week, and only $23 \%$-most of them working families facing cuts in their housing benefit -lose out. ${ }^{7}$ The picture is very different for other types of claimant. Fifty per cent of young single claimants, $59 \%$ of pensioner couples, and $82 \%$ of other childless couples stand to lose benefit, although some current claimants are covered by special transitional protection.

Lone parents fared less well than other families, although there is no evidence that their needs are any less, indeed quite the contrary. ${ }^{8}$ Only $50 \%$ of lone parents claiming benefit gained from the reform while $39 \%$, few of whom had their benefit protected, lost an average of $£ 2.90$ per week. 


\section{Forebodings}

On paper, the reforms mean that in a full year $£ 191$ million of means tested benefit will be redirected to families with children and, notably, to traditionally two parent units. The official figures, however, ignore the abolition of single payments, one off lump sum payments made to supplementary benefit claimants in order to meet exceptional needs, and their replacement by loans under the social fund. For most families on income support the loss of single payments will be more than the increase in weekly benefit. ${ }^{9}{ }^{10}$

Also, while the structure of child benefit remained intact the government chose not to increase the rate of benefit in line with inflation. This resulted in an annual saving of $£ 120$ million. Child benefit ( $£ 7.25$ per week) now equates with less than half the allowance payable for a 10 year old on income support (including the family premium) and represents less than a third of the direct costs attributable to a child of that age. ${ }^{11}$ However, the government gives greater priority to reducing the risk of poverty among families than to making a general contribution to the costs of bringing up children. The deindexing of child benefit had no effect on families in receipt of means tested benefits although it reduced the real incomes of seven million other families with children.

The social security green paper defended child benefit, which it described as 'simple, straightforward [and] well understood. ${ }^{5}$ But, current ministers believe that it is 'ill-targeted' and that it is consequently not meeting genuine need. ${ }^{12}$ If child benefit is phased out, or in other ways reduced in value, it will erode still further society's contribution to meeting the very real costs of children, a contribution which in the 1950 s was higher than it is today. ${ }^{13}$

In sum, the government has funded improved benefits for the poorest children by taking benefit away from other claimants. Additional moves in this direction, which seem likely to involve further reductions in the value of child benefit, will mean that the needs of the most deprived will be paid for by families who are themselves at the most financially vulnerable stage of the life cycle. ${ }^{14}$

All the official statistics quoted in this annotation are for Great Britain.

\section{References}

I Reform of social security. Volume 3. Background papers. London: HMSO, 1985. (Cmnd 9519.)

- Berthoud R. The reform of supplementary benefit. London: Policy Studics Institute, 1984.

${ }^{3}$ McCarthy M. Campaigning for the poor. London: Croom Hclm. 1986.

+ Reform of social security. Volume I. London: HMSO, 1985. (Cmnd 9517.)

5 Reform of social security. Volume 2. Programme for change. London: HMSO, 1985:47. (Cmnd 9518.)

" Timmins N. Low-pay workers to receive more help. The Independent 1987. 28 Oct. 329:6.

7 Department of Health and Social Sccurity. Impact of the reformed structure of income-related benefits. London: DHSS, 1987.

* Millar J, Bradshaw J. The living standards of lone-parent families. Quarterly Journal of Social Affairs 1987:3.4.

"Berthoud R. (Quoted in Timmins N.) Biggest losers will be worst off. The Independent 1987. 28 Oct, 329:6.

10 Berthoud R. Selected social security. London: Policy Studics Institute, 1986

"Mitchell D, Cooke K. The costs of childrearing. In: Walker R, Parker G, eds. Money matters. London: Sage, 1988:27-45.

12 Timmins $N$. Child benefit to be frozen in wide-ranging reforms. The Independent 1987. 28 Oct, 329:6.

1.3 Child Poverty Action Group. Child benefit under threat. London: Child Poverty Action Group, 1985.

it O’Higgins M, Bradshaw J, Walker R. Income distribution over the life cycle. In: Walker R, Parker G, eds. Money matters. London: Sage, 1988:227-54.

ROBERT WALKer Institute for Research in the Social Sciences and the Social Policy Research Unit, University of York YOI 5DD 